\title{
Job Satisfaction and Occupational Stress among Permanent and Temporary School Teachers
}

\author{
Dr. Tribhuvan Sunil Laxman ${ }^{1 *}$
}

\section{ABSTRACT}

Aim of the Study: 1.To search the job satisfaction among permanent and temporary school teachers. 2. To examine the occupational stress among permanent and temporary school teachers. 3. To find out the negative correlation found between job satisfaction and occupational stress among school teachers. Hypotheses: 1. there is no significant difference between among permanent and temporary school teachers dimension on job satisfaction. 2. There is no significant difference between among permanent and temporary school teachers dimension on occupational stress. 3. There is negative correlation between job satisfaction and occupational stress among school teachers. Sample: Total 120 school teachers were selected. Among them 60 among permanent school teachers and 60 among temporary school teachers. The age range of school teachers were 20 to 30 years $(M=26.45, S D=5.78)$. Non-probability purposive sampling was used. Tools 1. Teacher Job Satisfaction Questionnaire (TJSQ): (1996) this scale was constructed and standardized by Dr. Pramod Kumar and D. N. Mutha. Occupational Stress Index (OSI): This scale was constructed and standardize by Dr. A. K. Srivastava and A. P. Singh. Variable: Independent variable: Type of School Teacher a) among permanent b) temporary. Dependent Variable: 1. Job Satisfaction 2. Occupational Stress Conclusion: 1. permanent school teachers found significantly high job satisfaction than the temporary school teachers. 2. Temporary school teachers found significantly high occupational stress than the temporary school teachers.3. There is negative correlation found between job satisfaction and occupational stress among school teachers.

Keywords: Job Satisfaction, Occupational Stress, Permanent and Temporary School Teachers

Teachers are an essential link in the transmission of educational opportunity to poor children. Teacher job satisfaction has, in turn, been tied to teachers' work performance, including teachers' involvement, commitment, and motivation on the job. Teacher job dissatisfaction is closely associated with teacher absenteeism and a tendency toward attrition from the teaching

\footnotetext{
${ }^{1}$ Assistant Professor, Department of Psychology, Shri Bankatswami College, Beed, India *Responding Author

Received: February 22, 2017; Revision Received: March 25, 2017; Accepted: March 29, 2017

(C) 2017 Tribhuvan S; licensee IJIP. This is an Open Access Research distributed under the terms of the Creative Commons Attribution License (www.creativecommons.org/licenses/by/2.0), which permits unrestricted use, distribution, and reproduction in any Medium, provided the original work is properly cited.
} 


\section{Job Satisfaction and Occupational Stress among Permanent and Temporary School Teachers}

profession. Teacher commitment may also be an important factor deter-mining the successful implementation of educational reforms in schools. In China, the current era of educational reforms aims to bring about a shift toward more student-centered teaching and learning, a greater emphasis on critical thinking and the application of skills, and the establishment of a more democratic classroom environment. The implementation of these reforms will likely require greater levels of teacher initiative and innovation, making teacher commitment and motivation increasingly important. Disengaged teachers are unlikely to inspire student engagement or, consequently, student achievement.

According to Locke (1969) job satisfaction has been defined as a "pleasurable or positive emotional state resulting from the appraisal of one's job or job experiences". Satisfaction with various aspects of occupational stress experiences as difficult to characterize with other forms of everyday experiences (Cook et. al. 1981). For example, job satisfaction among teachers in higher secondary level schools, where students principal, typically have closed working relationships with their teachers may be influenced by the teachers' assessment of top management. Job satisfaction is an emotional relation to an employee's work condition. Job satisfaction is defined to be an overall impression about one's one job in terms of specific aspects of the job (work, pay promotion, co-workers, job in general). Job satisfaction also an extension over a taff member has favorable or positive feeling about work or the work environment (De Nobile 2003). It refers to the employee reactions towards their work experiences (Berry 1997) and work situations in the organizations (wood, wood and Boyd 2007). Smilansky (1984) observed teachers' work satisfaction and revealed that teachers' general satisfaction and stress at work were related mostly to their reported feelings about happening within class (such as relations with pupils, the process of teaching, and pupil behaviour in school) rather than to administrative or policy questions (such as degree of work autonomy, relations with principals).

Despite the fact that high-quality teachers are more difficult to recruit and retain in rural communities, there has been little investigation of the association between teacher satisfaction and such community characteristics as poverty, remoteness, and social resources. To date, researchers have focused on the relationships between teacher job satisfaction and individual and job characteristics. This research has taken two main approaches: a focus on facet-specific job satisfaction and an emphasis on understanding teachers' overall sense of satisfaction with their job. The first approach has sought to measure the extent to which teachers are satisfied with specific aspects of their job. These include remuneration, physical working conditions, and quality of relationships with supervisors and colleagues, quality of supervision, workload, teachers' social status, opportunities for personal growth and promotion, teachers' skills and professional accomplishments to date, degree of decision-making autonomy, and characteristics of the educational system. 
Job Satisfaction and Occupational Stress among Permanent and Temporary School Teachers

In contrast, the second approach has sought to link characteristics of schools and teachers to overall job satisfaction. This approach uses a global measure of teacher satisfaction against which a variety of school and teacher explanatory variables are tested via multivariate analyses. Teacher stress seems to be a universal phenomenon in Western countries, a phenomenon that has-been recognized for over more than 25 years and across many (e.g., Borg \& Riding, 1991). Teacher stress can be defined as the experience by a teacher of unpleasant negative emotions such as anger, frustration, anxiety, depression and nervousness, resulting from some aspect of their work (Kyriacou 2000). Since the early 1970s, the amount of research on teacher stress has T. Cox, Mackay, S. Cox, Watts, and Brockley (1978) reported that more than 60 per cent of teachers considered working as the main source of stress in their lives. Kyriacou (1980) revealed that teachers, when compared to people in other professions, teachers do experience a higher level of stress than many other professionals.

\section{Aim of the Study}

1. To search the job satisfaction among permanent and temporary school teachers.

2. To examine the occupational stress among permanent and temporary school teachers.

3. To find out the negative correlation found between job satisfaction and occupational stress among school teachers.

\section{Hypotheses}

1. There is no significant difference between among permanent and temporary school teachers dimension on job satisfaction.

2. There is no significant difference between among permanent and temporary school teachers dimension on occupational stress.

3. There is negative correlation between job satisfaction and occupational stress among school teachers.

\section{Sample}

Total 120 school teachers were selected. Among them 60 among permanent school teachers and 60 among temporary school teachers. The age range of school teachers were 20 to 30 years (M $=26.45, \mathrm{SD}=5.78$ ). Non-probability purposive sampling was used.

\section{Tools}

1) Teacher Job Satisfaction Questionnaire (TJSQ): (1996)

This scale was constructed and standardized by Dr. Pramod Kumar and D. N. Mutha. That test consists of 29 items, each item 'YES' 'NO' type alternatives. Reliability of the test was found by test retest method, and it was found to be .85 . Validity Face validity in that questionnaire is very high. 


\section{2) Occupational Stress Index (OSI):}

This scale was constructed and standardize by Dr. A. K. Srivastava and A. P. Singh. The inventory consists of 46 items, each item is provided with five alternatives 'Strongly Agree', 'more agree', 'agree', 'disagree', and 'disagree', Reliability of the inventory was found by test retest method, and it was found to be .93 . The correlation between the scores on the occupational stress inventory and the measure of the job anxiety (Srivastava, 1974) was found to be $.59(\mathrm{~N}=$ 400). The employee's scores on occupational stress inventory have been found to be positively correlated with their scores on the measure on mental health, standardized by Dr. O. N. Shrivastava.

\section{Variable}

Independent variable

Type of School Teacher $\quad$ a) Permanent $\quad$ b) Temporary

Dependent Variable

1. Job Satisfaction 2. Occupational Stress

\section{STATISTICAL ANALYSIS AND DISCUSSION}

Table no. 01 Significance difference between permanent and temporary school teachers in term of their job satisfaction and occupational Stress.

\begin{tabular}{|c|c|c|c|c|c|c|c|c|c|}
\hline \multirow[b]{3}{*}{ Dimension } & \multicolumn{6}{|c|}{ Type of School Teachers } & \multirow{3}{*}{ t- ratio } & \multirow{3}{*}{ df } & \multirow{3}{*}{$\mathbf{p}$} \\
\hline & \multicolumn{3}{|c|}{ Permanent $(\mathbf{N}=60)$} & \multicolumn{3}{|c|}{ Temporary $(\mathbf{N}=60)$} & & & \\
\hline & Mean & SD & SE & Mean & SD & $\mathrm{SE}$ & & & \\
\hline Job Satisfaction & 24.59 & 4.10 & 0.53 & 17.55 & 4.61 & 0.60 & $8.84 * *$ & 118 & $<.01$ \\
\hline $\begin{array}{l}\text { Occupational } \\
\text { Stress }\end{array}$ & 114.62 & 5.03 & 065 & 141.52 & 4.28 & 0.55 & $31.54^{* *}$ & 118 & $<.01$ \\
\hline
\end{tabular}

$\mathbf{0 . 0 1}=2.62, \quad 0.05=1.98$

From the above table mean of job satisfaction score of permanent school teachers mean is 24.59 and temporary school teachers mean is 17.55 . The difference between the two mean is highly significant at both level (' $\mathrm{t}$ ' $=8.84$, df $=118, \mathrm{P}<0.01$ ) and it is concluded that the permanent school teachers have significantly high job satisfaction than the temporary school teachers. Similar result found that the Kaur Sarbjit and Kumar Dinesh (2008) government college teachers are more satisfaction than the non-government college teachers.

From the above table mean of occupational stress score of permanent school teachers mean is 114.62 and temporary school teachers mean is 141.52 . The difference between the two mean is highly significant at both level (' $\mathrm{t}$ ' $=31.54$, df $=118, \mathrm{P}<0.01$ ) and it is concluded that the temporary school teachers have significantly high occupational stress than the permanent school teachers. Similar result found that the Kaur Sarbjit and Kumar Dinesh (2008) government college teachers are more occupational stress than the non-government college teachers. 
Job Satisfaction and Occupational Stress among Permanent and Temporary School Teachers

Table no. 02 ' $r$ ' showing the significance of relationship between job satisfaction and occupational stress among granted school teachers

\begin{tabular}{|lllcc|}
\hline Dimensions & $\mathbf{N}$ & $\mathbf{r}$ & DF & P \\
\hline $\begin{array}{l}\text { Job Satisfaction } \\
\text { Occupational Stress }\end{array}$ & 120 & -.53 & 118 & .01 \\
\hline
\end{tabular}

The results displayed in table no. 02 clearly indicated the significant relation between job satisfaction and occupational stress. This study also suggests that occupational stress is negatively associated with job satisfaction and occupational stress $(\mathrm{r}=-.31$, $\mathrm{df}=118, \mathrm{P}<.01)$. Negative Correlation between job satisfaction and occupational stress.

Nilufar, A., Abdullah, Z., Fie, D.Y.G. \& Alam, S.S. (2009) Similar result found that there is significant negative relationship between job stress and job satisfaction. Another study $\mathrm{K}$ Chandraiah et al (2003) higher level of job stress and job satisfaction has been found significant relationship between different age groups and also shown that the age was found to be negatively correlated with occupational stress and positively with job satisfaction. One study of general practitioners in England identified four job stressors that were predictive of job dissatisfaction (Cooper, et al., 1989).

In other study, Azman Ismail (2009) demonstrated that level of physiological stress has increased job satisfaction, and level of psychological stress had not decreased job satisfaction. Teacher job satisfaction and stress can have both economic and personal implications as it can lead to stressrelated employee absenteeism, burnout and a negative impact on pupil outcomes (Kyriacou, 1987). According to K Chandraiah et al (2003) higher level of job stress and job satisfaction has been found significant relationship between different age groups and also shown that the age was found to be negatively correlated with occupational stress and positively with job satisfaction. One study of general practitioners in England identified four job stressors that were predictive of job dissatisfaction (Cooper, et al., 1989).

\section{CONCLUSION}

1. Permanent school teachers found significantly high job satisfaction than the temporary school teachers.

2. Temporary school teachers found significantly high occupational stress than the temporary school teachers.

3. There is negative correlation found between job satisfaction and occupational stress among school teachers.

\section{Acknowledgments}

The author appreciates all those who participated in the study and helped to facilitate the research process. 
Conflict of Interests: The author declared no conflict of interests.

\section{REFERENCES}

Chandraiah K., S.C Agrawal, et.al.(2003). Occupational Stress and Job Satisfaction among Managers. Indian Journal of Occupational and Environmental Medicine Vol. 7, No. 2.

Cook J.D., S.J. Hepworth, et.al. (1981). The Experience of Work. London: Academic Press.

COOPER C.L.,ROUT,U.\&FARAGHER B. (1989). Mental health, job satisfaction and Job stress among general practitioners. British Medical Journal , 298 , 366. 370

Cox, T., Mackay, C. J., Cox, S., Watts, C., \& Brockley, T. (1978, September). Stress and wellbeing in school teachers. Psychological response to occupational stress. Conference conducted at the meeting of the Ergonomics Society, University of Nottingham, Nottingham.

D. Chapman and M. A. Lowther, “Teachers' Satisfaction with Teaching,” Journal of Educational Research 75, no. 4 (1982): 241-47.

Emily Hannum and Albert Park, "Children's Educational Engagement in Rural China" (unpublished manuscript, Sociology Department, University of Pennsylvania, Philadelphia, 2003)

F. Herzberg, B.Mausner, R. O. Peterson, and D. F. Capwell, Job Attitudes: Review of Research and Opinion (Pittsburgh: Psychological Service of Pittsburgh, 1957).

ISMAIL, A.; MASHKURI, A.H.; SULAIMAN, A.Z.; HOCK, W.K. (2011). Interactional justice as a mediator of the relationship between pay for performance and job satisfaction. Intangible Capital, 7(2): 213-235. http://dx.doi.org/10.3926/ic.2011.v7n2.p213-235.

Kaur Sarbjit and Kumar Dinesh (2008) Comparative Study Of Government And NonGovernment College Students In Relation To Job Satisfaction And Job Stress: online submission. http//www.eric.ed.gov. retrieved on 9-10-2008.

Kyriacou, C. (1980). Coping actions and occupational stress among school teachers. Research in Education, 24, 57-61.

Kyriacou, C. (1987), Teacher stress and burnout: An international review. Educational Research, 29, $146-152$.

Kyriacou, C. (2000). Stress-busting for teachers .Cheltenham: Nelson Thornes.

Kyriacou.C. (2001). Teacher stress: directions for future research. Educational Review, vol 53, no 1 , pp 27-35.

Liu Haiyan, An analysis of various factors influencing middle school and elementary school teacher motivation in economically underdeveloped areas. 1 (1995): 45-49;

Locke, E. A. (1976). The Nature and Causes of Job Satisfaction," in Handbook of Industrial and Organizational Psychology, ed. M. D. Dunnette, Chicago, III: Rand McNally.

Nilufar, A., Abdullah, Z., Fie, D.Y.G. \& Alam, S.S. (2009). A study of job stress on job satisfaction among university staff in Malaysia: Empirical study. European Journal of Social Sciences. 8 (1), 121-131. 
Job Satisfaction and Occupational Stress among Permanent and Temporary School Teachers

Pramod Kumar, M.A. \& D.N.Mutha (1996) Manual for Teacher Job-Satisfaction Questionnaire (TJSQ), (1996 Revision) .

Smilansky, J. (1984). External and internal correlates of teachers' satisfaction and willingness to report stress. British Journal of Educational Psychology, 54, 84-92.

Srivastava, A.K. \& Singh, A.P. (1981) Manual of the Occupational stress Index, Department of Psychology, Banaras Hindu University, Varanasi

Troman, C. \& Woods, P. (2001).Primary teachers' stress. London: Routledge Falmer Vandenberghe, R. \& Huberman, M. (1999).Understanding and preventing teacher burnout: a sourcebook of international research and practice. Cambridge: Cambridge University Press.

Xin Ma and Robert MacMillan, "Influences of Workplace Conditions on Teachers' Job Satisfaction,” Journal of Educational Research 93, no. 1 (1999): 39.

How to cite this article: Tribhuvan S (2017), Job Satisfaction and Occupational Stress among Permanent and Temporary School Teachers, International Journal of Indian Psychology, Volume 4, Issue 2, No. 95, ISSN:2348-5396 (e), ISSN:2349-3429 (p), DIP:18.01.170/20170402, ISBN:978-1-365-84231-3 